\title{
Energy-Saving Electronics Production in Viet Nam: Rise and Problems of Sustainable Development
}

\author{
Tran Thi Bich $\mathrm{Ngoc}^{1, *}$, and Dao Thanh Binh ${ }^{1}$ \\ ${ }^{1}$ Hanoi University of Science and Technology, 1 Dai Co Viet, Hanoi, Viet Nam
}

\begin{abstract}
Electronic industry is the basis for the growth of industrial production in ASEAN countries, and represents the main lever of economic development when the region moves up to higher added value using modern technological solutions. At the same time, modern environmental imperatives require the electronics industry to make a significant contribution to reducing environmental stress and lowering energy consumption. This contribution is the production of energy-saving devices. Viet Nam's modern industry is increasing the production of electronic energy-saving devices, but still has problems, such as low added value, spontaneous structure, import dependence in production, lack of unified state administration, and the quality of training of labor resources. In the framework of this article, the authors investigated the state of the electronic industry in Viet Nam by analyzing its successes and shortcomings in recent years compared with the countries of Southeast Asia. The authors' proposals as the results of the study can be recommended for further development of a policy for the progress of energy-saving production in the electronic industry of Viet Nam and an import substitution program in the country's industry as a whole for a new period.
\end{abstract}

\section{Introduction}

Electronic industry is an industry for the production of electronic components and products and is one of the most important for any state, since it provides an electronic component base for almost all other sectors of the economy [1]. The release of energysaving means differs from other industries in a high level of concentration, specialization and integration of production [2-4]. In addition, the very release of products for energy saving is characterized by a high level of international integration in production, the high technology level in its manufactured goods, short product life cycle and, therefore, high added value [5-6]. In the modern world, the state of electronic energy-saving means determines technological independence, state security and the pace of modernization of the country.

\footnotetext{
* Corresponding author: bichngoc2201@gmail.com
} 
Viet Nam electronics industry was formed in the late 1980s and has been gradually improving since 2000. Its fast pace of development has gained since 2010, when foreign direct investment in the Viet Name economy is reviving impressively. Being a key sector of industrial production, electronic industry occupies an important place in the economy of Viet Nam and has an impact on the development of other industries. The development of the electronic industry also accelerates the process of industrialization in the country, stimulates the expansion of the service sector and provides the working population with jobs. The electronics industry in Viet Nam is characterized by rapid growth in production, expanding the range of products (semiconductors, integrated circuits, Printed Circuit Boards-PCBs, etc., as well as electronic energy-saving means (high-precision sensors, data integrators, equipment dispatch systems, components and accessories).

\section{Materials and Methods}

Since 2007, the Government of Viet Nam approved the "List of priority and key industries for the period from 2007 to 2010 with a vision to 2020.", according to which electronics, information and telecommunication technologies (ITT) were identified as key out of 10 priority industries. In accordance with this, the Government has established a number of measures to support their development.

The Decision number 879 / QĐ-TTg on June 9, 2014 approved the "Industrial development strategy of Viet Nam till 2025 with a vision to 2035", which re-emphasized that the production of energy-saving electronics and telecommunications is one of the three groups of highest priority branches of economy (manufacturing, electronics and telecommunications, new energy and renewable energy sources). By definition Strategy, the electronics industry will be a priority to develop a leading way compared with other industries; production of electronic industry represents a high technology and is widely used in energy-saving, creates the effect that the objective and prospective conditions for conversion into other areas of the national industry.

The data statistics shows the fast pace of development of the electronics industry. In 2000-2010 the growth of gross output of the electronic industry of Viet Nam has averaged $20-30 \%$ per year, especially increased by $96 \%$ in 2011 . Industrial production index of the sector in 2014 - 2015 was respectively 138.2 and $137.0 \%$ [7].

In 2015, the value of exports of electronic products in Viet Nam amounted to $\$ 48.8$ billion, beating Malaysia (about 43.64 billion) [8], and Thailand (32.2 billion) [9]. In 2016, according to the General Administration of Customs, the export volume of electronic products (including electronics for energy saving) reached the amount of US \$ 56.231 billion, up $15.23 \%$ compared with 2015 , contributes $32 \%$ of total export value of Viet Nam (US \$ 176.63 billion in 2016). [7]

By the scale of production, according to official data of the Central Statistical Management of Viet Nam by the end of 2015, companies operating encounted up to1145 with the total number of people employed in the production in the electronics industry of 497037.

Viet Nam electronic industry uses preferential conditions for the development and transformation into a center of production of electronic energy-saving in the world:

1. The trend towards international economic integration of Viet Nam speeds up the process of rapprochement to other states in the region and the world in the field of economics, finance, distribution of labor. Participation in the global integration of electronic energy-saving production creates for Viet Name electronics industry the real opportunities to enter the world market and to enter more deeply into the global value chains. Accession to the WTO, ASEAN Economic Community and participation in many 
free trade agreements with the European Union, the Eurasian Union shall contribute to the promotion of products to the regional and global market.

2. The inflow of global investments can turn Viet Nam into the second center of world production of electronics after China. According to experts, published by the American "Journal of Commerce", now a number of large multinational corporations of the world electronics industry from the United States, Japan, South Korea is gradually moving production from China to the countries of Southeast Asia. [10-11] Possible competitors of Viet Nam in the region for the production of energy-saving electronics and computer components are China, Malaysia and Thailand. However, due to the political stability, Viet Nam has become one of the areas where the moves of foreign capital make its inflow, which makes Viet Nam electronics industry the new impetus to the further development of the electronic energy-saving means. Large global corporations in the field of information technology and electronics continue to invest billions of dollars in projects in Viet Nam. The accumulated amount of direct foreign investment in the electronics industry to date has reached $\$ 20$ billion, including the Samsung - 14,8 billion, Intel -1 billion, LG -1.5 billion, Microsoft - 302 million, Japanese manufacturer of optical sensors and micromotors (Nidec) - 1 billion, Foxconn Group (Taiwan - the production of electronic components) - 1 billion). [12]

3. The attractiveness of the investment environment is one of the advantageous conditions for attracting foreign direct investment. According to Viet Namese law number 32/2013 / QH13 of June 19, 2013 on amendments and additions to the articles of the Law on Corporate Income Tax and other legal instruments of Viet Nam, all organizations and enterprises use the benefits of electronic industry and support from the State, established for subjects high-tech production, namely:

- exemption from the payment of land rent for 11 years for investment projects in areas with special socio-economic difficulties; projects related to the list of specific sectors for investment in areas with socio-economic difficulties; or 15 years, if the investment is implemented in areas with special socio-economic difficulties;

- the provision of benefits in relation to corporate income tax rate of $10 \%$ applied for 15 consecutive years since the introduction of the taxable income, including: exemption from corporate income tax for 4 years; $50 \%$ reduction for not more than 9 years of follow-up;

- tax exemption on the import of equipment, materials, vehicles and other goods for investment projects in Viet Nam.

These incentives are considered to be more attractive than those in Thailand, where the tax benefits from the government included an exemption from corporate income tax for 8 years, and a decline of $50 \%$ over the next 5 years; tax exemption on equipment imports. In the region of corporate income tax rate in Viet Nam, Thailand accounted for $20 \%$, higher than in Singapore (17\%) and lower than in Malaysia and Indonesia (25\%). [13].

Despite the successes and large-scale development, production of electronic energysaving means in the electronics industry of Viet Nam is evaluated as a new sub-sector, which is facing problems directly affecting its efficiency and competitiveness.

1. The low value added and underdeveloped supporting industries. In recent years, Viet Nam electronic industry in general is gaining significant output growth (an average of $37 \%$ per year) and reaches a large volume of exports, but it is not enough to earn the added value in proportion.

2. The tendency to assembly of products for multinational corporations; lack of own brands and dependence on foreign investors in the choice of technologies and products. The energy-saving production in the electronic industry in Viet Nam has some restrictions as the assembly of products of famous brands and manufacture of parts and accessories. The reasons for this are as follows: (i) the pressure from a competitor with other producers in the market; (ii) weak market conditions and a lack of knowledge about the market and 
consumers from Viet Nam producers; (iii) high dependence on imported components, equipment and software. Such import dependence cannot be solved in one day. In our opinion, it can be added to the main reason as follows: the weak $\mathrm{R} \& \mathrm{D}$, dependence on imports of important components due to lack of domestic production of critical parts. For this reason, the production of Viet Nam electronics industry depends on the well-known corporations such as like Samsung, LG, Intel.

3. The lack of a unified plan for the development of Viet Nam electronics industry and a uniform control for a long time. Viet Nam electronics industry since the advent existed almost spontaneous manner without a development plan, and the attention of the competent authorities for 20 years. Only in 2007 for the first time, "General electronics industry development plan of Viet Nam for the period until 2010 with a vision to 2020" were approved by the Government decision number 75/2007 / QĐ-TTg dated May 28, 2007. Under the plan, the state management of Viet Nam electronics industry is the responsibility of the Ministry of Information and Communications. In our opinion, there is a number of problems: it is necessary to solve the basic issues relating to investment, production and sales of electronics for energy saving, financial support for the activities and training. But these functions are respectively implemented by the Ministry of Planning and Investment, Ministry of Industry and Trade, the Ministry of Finance and the Ministry of Education. At the same time, other ministries carry out only a part of them relating to problems associated with the production of energy-saving electronics, which reduces to the duplication of functions, untimely responses and slow decision-making problems, and finally, the inhibition of the development of the entire electronics industry.

4. The business environment and competitiveness issues. In the ranking of Doing Business 2017, published recently by the World Bank, Viet Nam occupies the 82th place of 190 classified countries and economies, while Malaysia - the 23rd, Thailand - the 46th, China - the 78th and Indonesia - the 91st. Although much has been done, but on the Global Competitiveness Index of the World Economic Forum (World Economic Forum / The Global Competitiveness Report 2016-2017) with an index of 4.3 / 7 rating Viet Nam occupies the 60th place out of 138 economies studied. Average ratings and the ratings given by 12 targets, determining national competitiveness, namely the quality of institutions (index and rating) - 3,8 and 82; infrastructure 3.9 and 79; macro stability - 4.5 and 77; health and primary education $-5,8$ and 65 ; higher education and training $-4,1$ and 83 ; efficiency of the market for goods and services $-4,2$ and 81 ; labor market efficiency $-4,3$ and 63; development of the financial market - the 3.9 and 78 ; level of technological development 3,5 and 92; the size of the domestic market - 4.8 and 32; the competitiveness of companies - 3.6 and 96; innovation potential - 3.3 and 73 [14].

Consequently, in spite of the open investment policy and measures to improve the business environment, Viet Nam still is in a group with the threat of the backlog, and should improve the performance of the release of energy-saving electronics and, thereby, increase the competitiveness of the electronics industry at the regional and global market.

\section{Results and Discussion}

Studying the state of Viet Nam electronics industry, the authors believe that to solve the problems in the production of energy-saving electronics the approach is required, which includes the following comprehensive measures aimed at its development:

1. Measures to strengthen state regulation:

- transfer function of state regulation of the electronics industry from the Ministry of Communications to the Ministry of Industry and Trade as well as the implementation of management of the industry in general is a function of Industry and Trade, or create by the 
Government a special body for an overall settlement of the electronics industry and coordination of related ministries and agencies;

- to develop measures to control the phenomenon of transfer pricing of transnational corporations and their businesses in Viet Nam;

- improve the business environment for all indicators in determining national competitiveness.

2. Measures for the development of supporting industries for the production of energysaving electronics:

- develop further measures to encourage and attract investment in supporting industries and provide incentives and financial support, respectively, the Program of development of supporting industries for the period 2016-2025 years, with attention given to the development of specific efforts and activities to address the problems of import substitution;

- to develop a range of priority of energy-saving electronic products (individual components and parts and components) and create the conditions for the needs of the domestic assembly plants and external market;

- expand and improve conditions for the energy-saving electronic other areas, such as banking, transport services.

3. Measures for the formation of industrial clusters:

- to create an e-based clusters of industries with industrial parks in Ho Chi Minh City and Hanoi, in Haiphong, Bac Ninh, and Thaynguen Bình Dương Province, with the focus assembly plants and companies supporting industries;

- provide incentives and financial support to the local and foreign investors and to any businesses and individuals which wish to conduct their business and services in the cluster, with the highlight the attention and support to small and medium-sized enterprises according to the established by the government for their orders.

4. Measures to improve the quality of labor resources:

- to draw the national educational institutions onto the training of manpower for all sectors of the economy, including the labor in electronics industry, create research centers and institutes, while enhancing the cooperation on the type of public-private partnerships; focusing attention and efforts on training of specialists and workers;

- to take into account the implementation of the reforms carried out by the Ministry of Education for the restructuring of the educational system in order to optimize the relationship between higher, secondary and primary education in order to meet the increasing demand of the labor market;

- to develop measures to strengthen the material-and-technical base of educational and training institutions, to improve the teaching staff;

- to form a close mutual cooperation between educational institutions and enterprises employers - to examine their demand for specialists in the field of energy-saving electronics and implement targeted training principle.

5) Measures of Innovation Policy:

- to identify the main types of advanced electronics for energy saving; enhance innovation in $\mathrm{R} \& \mathrm{D}$ in research institutions, universities and enterprises, at the same time orient their efforts on the research and development of new priority kinds of electronic products provided by the decision of the Prime Minister of the number 49/2010 / QĐ-TTg of July 19, 2010 on the nomenclature of priority high-tech and knowledge-intensive energysaving goods;

- to develop a policy to promote the commercialization and transfer of modern technologies in high-tech manufacturing processes for the production of energy-saving electronics. 


\section{Conclusion}

In conclusion, it should be noted that the producing of energy saving electronics as a fusion of modern scientific and technological achievements and technology, gains a paramount importance today. Virtually there is no area of human activity, where production of energy-saving electronics has not found its application. In Viet Nam, the electronics industry is recognized as a basic material production sector of the national economy. Its development has a direct impact on other industries and plays an important role in dealing with the process of industrialization and modernization in the country, as well with the growing worldwide trend of responsible environmental management.

\section{References}

1. Viet Nam General Statistical Office (2016). Review of the socio-economic situation in 2015 - index of industrial production. URL: https://www.gso.gov.vn/default.aspx?tabid=621\&ItemID=15507

2. S. Zhironkin, S. Demchenko, G. Kayachev, M. Ryzhkova, O. Zhironkina, E3S Web Conf., 41, 04011 (2018)

3. S. Zhironkin, S. Demchenko, G. Kayachev, E. Taran, O. Zhironkina, E3S Web of Conferences, 105, 03008 (2019)

4. S.A. Zhironkin, K.A. Kolotov, A.E. Genin, F.V. Agafonov, S.A. Kovalevsky, IOP Conf. Ser.: Earth Environ. Sci., 50:1, 012011 (2017)

5. S. Zhironkin, M. Gasanov, G. Barysheva, K. Kolotov, O. Zhironkina, E3S Web Conf., 15, 03012 (2017)

6. E.A. Gasanov, T.S. Boyko, N.S. Frolova, Economics and Innovation Management, 3, 4-8 (2018) DOI: 10.26730/2587-5574-2018-3-4-8

7. General Statistics Office Statistical Yearbook of Viet Nam (Statistics, Hanoi, 2017)

8. Rabobank in Malaysia. Foreign Trade in Figures. 2017. URL: https://rabowereldwijd.nl/malaysia-economic-and-political-outline/c/2245

9. OIE The Office of Industrial Economics, Thailand. Industrial Economic Conditions in 2015 and Outlook for 2016. (OIE, Bangkok, 2015)

10. G. Knowler, Factory shift from China to Viet Nam accelerates, Barclays data shows. The latest news from the Industry. URL: http://www.aslglobal.com/en/newsdetail?id=73

11. S. Zhironkin, D. Khloptsov, N. Skrylnikova, I. Petinenko, O. Zhironkina, E3S Web Conf., 41, 04010 (2018)

12. Gary Rynhart, Jae-Hee Chang, Phu Huynh, ASEAN in transformation: electrical and electronics: on and off the grid. Working Paper No.13 ILO. URL: http://www.ilo.org/public/english/dialogue/actemp/downloads/publications/2016/asean _in_transf_2016_r5_electr.pdf

13. Hirunya Suchinai, Thailand Investment environment and BOI Investment Promotion Policy. Thailand Board of Investment (South Korea, Changwon, 2003)

14. 2016 JETRO Survey on Business Conditions of Japanese Companies in Asia and Oceania.

URL: https://www.jetro.go.jp/ext_images/en/reports/survey/pdf/2013_05_01_biz.pdf 